\title{
Long-Term Storage of Vegetable Juices Treated by High Hydrostatic Pressure: Assurance of the Microbial Safety
}

\author{
Justyna Nasiłowska (D), Barbara Sokołowska, ${ }^{1,2}$ and Monika Fonberg-Broczek ${ }^{2}$ \\ ${ }^{1}$ Department of Microbiology, Prof. Wacław Dąbrowski Institute of Agricultural and Food Biotechnology, \\ 36 Rakowiecka Str., 02-532 Warsaw, Poland \\ ${ }^{2}$ Laboratory of Biological Materials, Institute of High Pressure Physics Polish Academy of Sciences, \\ 29/37 Sokołowska Str., 01-142 Warsaw, Poland \\ Correspondence should be addressed to Justyna Nasiłowska; nasilowska@ibprs.pl
}

Received 3 August 2018; Revised 30 October 2018; Accepted 29 November 2018; Published 12 December 2018

Guest Editor: María de Guía Córdoba

Copyright (C) 2018 Justyna Nasiłowska et al. This is an open access article distributed under the Creative Commons Attribution License, which permits unrestricted use, distribution, and reproduction in any medium, provided the original work is properly cited.

\begin{abstract}
Food business operators search for new, mild technologies, which extend the shelf life of product without changing the sensory and nutritional properties. High hydrostatic pressure (HHP) meets these requirements; however it also triggers sublethal injury of bacterial cells. Sublethal injuries could spoil the product during storage and potentially pose major public health concerns. This study aims to examine the changes of sublethally injured pathogens cells in two vegetable juices: carrot juice ( $\mathrm{pH}$ 6.0-6.7) and beetroot juice ( $\mathrm{pH} 4.0-4.2)$ that are induced by HHP (300-500 MPa). The possibilities of recovery of bacterial cells during 28 days of juices storage at two different temperatures $\left(5^{\circ} \mathrm{C}\right.$ and $\left.25^{\circ} \mathrm{C}\right)$ were determined using plate count methods. During the entire period of storage of carrot juice at refrigerated temperature, the propagation and regeneration of $L$. innocua strains were observed. Storage at $25^{\circ} \mathrm{C}$ showed that the number of these bacteria drastically decreased between 14 and 21 days. The above phenomenon was not detected in E. coli case. There was no cells recovery during long-term refrigerated storage for all strains in beetroot juice. However, in some cases spoiling of this product intermittently occurred at $25^{\circ} \mathrm{C}$ storage temperature. This work demonstrates that carrot juice supports growth and regeneration of HHP-sublethally injured L. innocua, while beetroot juice can be classified as a safe product.
\end{abstract}

\section{Introduction}

Vegetable juices belong to the group of functional food and play an important role in human's diet. Some reviews of the previous studies indicated that they could help prevent several major civilization diseases, such as heart problems, cancer, diabetes, and obesity, as well as the prevention and alleviation of several micronutrients deficiencies [1-3]. In view of its health-related properties, they have attracted great interest among consumers. Both carrot (Daucus carota) and red beet (Beta vulgaris) are traditional and popular vegetables in many parts of the world. They contain natural antioxidants, high amount of vitamins, minerals, and trace elements [4-8]. However, raw vegetable juices have limited market potential, due to its short shelf life, and should normally be consumed within a few days [9]. Moreover, vegetable juices are the most contaminated among the commercially available raw juices
$[10,11]$. The initial microbial load is typically approximately $6.0 \log \mathrm{CFU} / \mathrm{mL}[11,12]$, including pathogens [11, 13]. One of the reasons of vegetable juice contamination with potentially hazardous microorganisms is natural fertilizers that are often applied in ecological agricultures [14]. Pathogenic bacteria survive in soil for a relatively long period of time, depending on environmental conditions. It is significant that the low-acid condition of raw, unprocessed vegetable juices is conductive to the growth of pathogenic microorganisms, such as Salmonella spp., Listeria monocytogenes, Escherichia coli O157:H7, Staphylococcus aureus, or Campylobacter jejuni [11, 13-17]. Wherefore, some manufacturers lower $\mathrm{pH}$ of vegetable juices using ascorbic acid or addition of apple juice to extend the shelf life and provide safety of the fresh juice. Despite these efforts, the most often detected pathogens in unpasteurized fresh beetroot and carrot juices are Listeria species and coliforms $[11,18]$. 
High hydrostatic pressure (HHP) has been officially approved by The U.S. Food and Drug Administration, as a nonthermal pasteurisation technology [19]. Nowadays, HHP has attracted widespread attention of food industry members and is the most successfully commercialized nonthermal processing technology $[19,20]$. This technology enables better quality of food to be obtained, rather than that processed using traditional methods. Primarily, it not notably changes the sensory and nutritional attributes of product but reduces the microbial counts responsible for spoilage and for shortening the shelf life [21-26]. Despite the above benefits, HHP triggers sublethal injury of bacterial cells [27-31].

Generally, HHP induces varying levels of sublethal injury. High pressure changes cell morphology and genetic mechanism and inhibits the metabolic reactions, which are essential for the cell maintenance [26]. Magnitude of these phenomena may be different depending on the genus or even species of microorganism, type of substrate, and processing parameters. Different food preservation strategies bring different stress factors that affect the microbiota of product. Scientific research has yielded some important information on the factors, affecting the injuries and recoveries of bacterial cells in food matrices $[32,33]$. Nowadays, it is apparent that both phenomena depend on type of technology, as well as environmental conditions such as food $\mathrm{pH}$, storage temperature, addition of various components on the food including nutrients, preservatives, etc. The regulatory network allows the stressed bacteria to react on changes by activating the proper mechanism, which allows them to adapt [33]. Sublethally injured cells may exist in the population, although most microbes are killed. Moreover, food matrices can be bacteriostatic as well as bactericidal, due to intrinsic factors including water activity, $\mathrm{pH}$, salt content, etc. The injured cells can develop adaptive responses to stress, resuscitate in a medium containing the necessary nutrients, and grow during storage. On the other hand, the injured cells may develop sensitivity to physical and chemical environments, to which normal cells are resistant [33] and lose the ability to grow on defined culture media. The presence of sublethally injured cells in food poses major public health concerns and is crucial in assessing the microbial response to food preservation strategies [34]. On the other hand, only a small portion of merchant suppliers offer HHP-treated vegetable juices [25]. Moreover, no high pressure food is currently available under room temperature on the market $[20,26]$.

According to European Commission Regulation (EC) No. 2073/2005 [35] manufacturers are obliged to ensure microbial safety of food products up to the end of the declared shelf life. Apart from microbiological criteria for foodstuffs, above document specifies the methods to demonstrate the possibilities of propagation of microorganisms during the shelf life of the product. One of these tools is the microbiological challenge testing. Challenge testing is a practical study that evaluates the behaviour of crucial organisms (e.g., pathogens), which display opportunity of grow and/or survive in the food matrices and if so, how fast they will grow. Examined food product is contaminated by relevant microorganisms and then stored and tested for these organisms during shelf life $[36,37]$, which is used for estimation of the growth potential $(\delta)$.

The aim of this study was to evaluate the survival rate and the regeneration possibilities of HHP-sublethally injured bacterial cells in two types of vegetable juices during longterm storage at two different temperatures. In addition to this, the understanding of the behaviour of HHP-sublethally injured cells during storage may be helpful to design and control the process, as well as establish the hold time limits for storage.

\section{Materials and Methods}

2.1. Microorganisms and Growth Conditions. E. coli ATCC 7839 (obtained from American Typed Culture Collection, Manassas, USA) and L. innocua CIP80.11T (obtained from the Culture Collection of the Institut Pasteur, Paris, France) wild strains, which were isolated from unpasteurized, commercial beetroot juice, L. innocua 23/13 and E. coli 61/14, obtained from the Department's collection of Fruit and Vegetable Product Technology at IAFB (Warsaw, Poland), were used in this investigation. The strains were stored in a Cryobank at a temperature below $-27 \pm 3^{\circ} \mathrm{C}$ before using. First, pure culture immobilized on sterile beads was added to $10 \mathrm{ml}$ of sterile Brain Heart Infusion (BHI) broth (BioMerieux, I'Etoile, France). Broth subcultures were incubated at $37^{\circ} \mathrm{C}$ for $24 \mathrm{~h}$, then each overnight culture was moved with a $10 \mu \mathrm{L}$ loop on a Petri dish, with the usage of streak plate technique with Tryptic Soy (TSA) agar (Biocar Diagnostics, Beauvais, France) for E. coli or Tryptic Soy Yeast Extract (TSYE) agar (Biocar Diagnostics, Beauvais, France) for L. innocua. Next, the culture from the plate was added, using $10 \mu \mathrm{L}$ loop, to $250 \mathrm{~mL}$ Erlenmeyer flasks containing $200 \mathrm{~mL}$ of Tryptic Soy Broth (TSB) (Biocar Diagnostics, Beauvais, France), or Tryptic Soy Broth with Yeast Extract (TSBYE) (Biocar Diagnostics, Beauvais, France) in order, that prepare the second subculture, which was incubated at $37^{\circ} \mathrm{C}$ for $18 \mathrm{~h}$ to obtain the stationary phase culture. Then $10 \mathrm{~mL}$ of second subculture was added to fresh, sterile broth (TSB or TSYEB) and incubated at $37^{\circ} \mathrm{C}$ for $18 \mathrm{~h}$. The cultures were then harvested by centrifugation $(4000 \times \mathrm{g}, 10 \mathrm{~min}$., $4^{\circ} \mathrm{C}$ ). The sedimented cells were aseptically resuspended into phosphate-buffered saline (PBS, pH 7.4) and again centrifuged. The washing procedure was repeated twice more. Following this, the model of bacterial cells suspensions was prepared in PBS. Just before HHP treatment, pasteurized beetroot juice supplemented with $5 \%$ apple juice (Victoria Cymes, $\mathrm{pH}$ 4.0-4.2) and carrot juice (Vital Fresh, $\mathrm{pH}$ 6.06.7) were inoculated with bacterial suspensions, in an amount of about $7.0 \log \mathrm{CFU} / \mathrm{mL}$, determined by spread plating appropriate dilutions on to TSA/TSYEA, and transferred into sterile polyethylene tubes (Sarstedt, Newton, USA) in $13 \mathrm{~mL}$ portions in duplicate.

2.2. HHP Equipment. The samples were exposed to high pressure treatment, with the use of U 4000/65 apparatus (Unipress, Warsaw, Poland). The volume of the treatment chamber was $0.95 \mathrm{~L}$, and the maximum working pressure 
TABLE 1: High hydrostatic pressure conditions.

\begin{tabular}{lrr}
\hline Strains & beetroot juice & HHP parameters \\
& & pressure/time \\
\hline Listeria innocua CIP 80.11T & $300 \mathrm{MPa} / 5$ minutes & $400 \mathrm{MPa} / 5 \mathrm{minutes}$ \\
Listeria innocua-wild type strain 23/13 & $300 \mathrm{MPa} / 10$ minutes & $400 \mathrm{MPa} / 5 \mathrm{minutes}$ \\
Escherichia coli ATCC 7839 & $300 \mathrm{MPa} / 10$ minutes & $500 \mathrm{MPa} / 5 \mathrm{minutes}$ \\
Escherichia coli-wild type strain 61/14 & $300 \mathrm{MPa} / 10$ minutes & $500 \mathrm{MPa} / 5 \mathrm{minutes}$ \\
\hline
\end{tabular}

was $600 \mathrm{MPa}$. The pressure-transmitting fluid, that was used, was distilled water and polypropylene glycol $(1: 1, \mathrm{v} / \mathrm{v})$. The working temperatures of the apparatus range from $-10^{\circ} \mathrm{C}$ to $+80^{\circ} \mathrm{C}$. Pressure of up to $400 \mathrm{MPa}$ was generated in 70 $80 \mathrm{~s}$, and the release time was 2-4 s. Samples were subjected to high hydrostatic pressure at various pressure, depending on the strain and juice $(300,400,500 \mathrm{MPa})$, at an ambient temperature (i.e., approximately $20^{\circ} \mathrm{C}$ ) and held for 5 or $10 \mathrm{~min}$ (Table 1). The use of different pressure parameters was aimed at induction of the highest level of sublethal bacterial injuries in the sample. These process conditions trigger the highest level of sublethal injury of these cell strains and were chosen based on our earlier studies [38, 39]. Temperature increase, due to the adiabatic heating, was approximately $3^{\circ} \mathrm{C}$ per $400 \mathrm{MPa}$. The pressurization times reported do not include the come-up and come-down time. For each tested strain, juice, and storage temperature, the assays were performed with usage of the two independent samples, which were coming from the two independent processes. After the treatment, the samples were stored at $5^{\circ} \mathrm{C}$ and $25^{\circ} \mathrm{C}$ up to 28 days and periodically analyzed. Unpressurized samples were used as a control.

2.3. Plate Count Analytical Methods. The viability of each strain was assayed by counting colony-forming units immediately after HHP processing. Thereafter, both treated and untreated juices were enumerated at regular intervals during refrigerated storage. At each sampling time, a tube with the sample was opened aseptically and analyzed. Further decimal dilutions in Tryptone Salt Broth (Biokar Diagnostics, Beauvais, France), of each sample, were prepared. Appropriate dilutions of samples were spread on agars. Counts of total viable cells were determined by spread plate on TSA or TSYEA. Selective agars, that were agars supplemented with critical $\mathrm{NaCl}$ (POCh, Gliwice, Poland) concentration of $5 \%(\mathrm{w} / \mathrm{v})$, were used to determine noninjured cells in the population. That was the maximum concentration of $\mathrm{NaCl}$ that caused no reduction in the colony count of unstressed cells, estimated in the preliminary trial. The number of sublethally injured survivors was quantified by the difference, between the viable and noninjured cells. Plates with nonselective agars were incubated for $24 \mathrm{~h} / 37^{\circ} \mathrm{C}$ and selective agars for $48 \mathrm{~h} / 37^{\circ} \mathrm{C}$. The plates containing less than $300 \mathrm{CFU} / \mathrm{mL}$ were selected for counting.

2.4. Statistical Analysis. Statistical analysis of the results was performed by two-way ANOVA statistical model with
Tukey's test, using Statistica version 13 (TIBCO Software Inc., Palo Alto, CA, USA). The differences were considered significant at $p<0.05$. Statistical comparison was made for results, obtained for strains of the same species at the same temperature and matrix.

\section{Results and Discussion}

3.1. Effect of Storage Temperature on E. coli and L. innocua in Vegetable Juices. In the present study, two types of high pressure treated-vegetable juices (beetroot and carrot) were analyzed during four weeks of storage time to test their microbiological safety. We tested if sublethally injured by HHP bacterial cells would be able to regenerate and survive in those vegetable juices. The second goal was to investigate if storage at ambient temperature would support the growth of HHP-treated bacteria in comparison to refrigerated conditions. As a preliminary experiment, we studied the effect of HHP on tested species, in both, previously mentioned types of juices in a range of pressure $200-500 \mathrm{MPa}$ up to 10 minutes. The next step that was done was the screening analysis to choose the parameters, which induce the highest level of sublethal injury of those bacterial strains. The results showed that in carrot juice pressure of $400 \mathrm{MPa}$ for 5 minutes triggers sublethal injuries of Listeria innocua strains, while extending the parameters inactivates these bacteria. In turn, Escherichia coli strains were sublethally injured under pressure of $500 \mathrm{MPa}$ for 5 minutes [data not shown]. Induction of sublethal injuries of those bacterial cells in beetroot juice needed milder parameters: $300 \mathrm{MPa}$ up to 10 minutes $[38,39]$. Because of the aforementioned, this experiment shows the results carried out only with the use of thoseparameters, which prompted the highest level of sublethal injuries (Table 1).

The survivability of strains, in untreated juice samples, is shown in Figure 1. Despite the acid pH of beetroot juice, significant decrease of population for all the tested strains was not observed during storage at both temperatures $(p \geq 0.05)$. Number of viable cells, of tested strains in beetroot juice at both temperatures, decreased by less than $1.0 \log \mathrm{CFU} / \mathrm{mL}$ during all period of storage. Exclusively, number of $L$. innocua wild type strain in beetroot juice, stored at $25^{\circ} \mathrm{C}$, reduced about $2.1 \log \mathrm{CFU} / \mathrm{mL}$. In carrot juice, stored at $5^{\circ} \mathrm{C}$ number of viable cells of tested strains was between 7 and 10 $\log \mathrm{CFU} / \mathrm{mL}$. During the entire period of storage, the viability of $E$. coli was stable, while the propagation of $L$. innocua was observed. Number of L. innocua in population had increased 


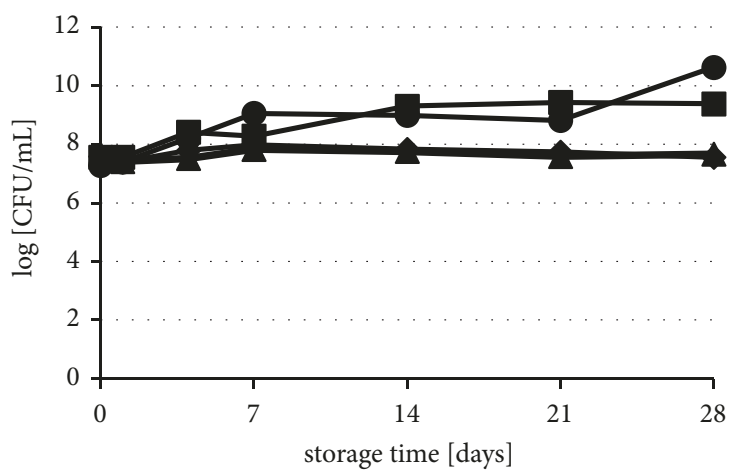

(a)

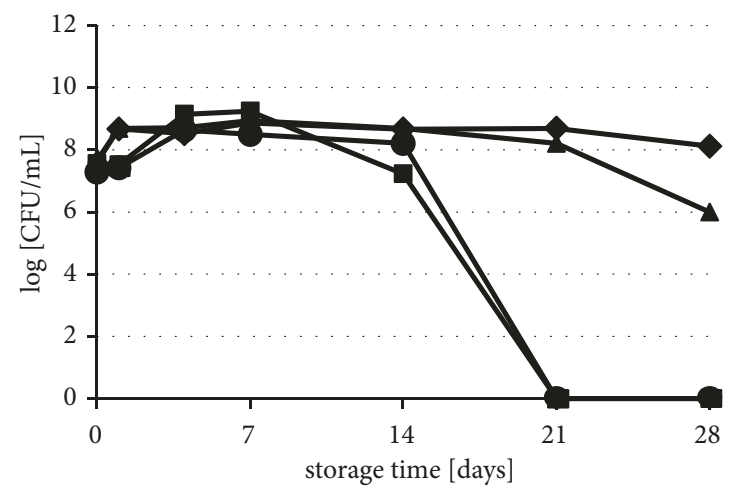

(c)

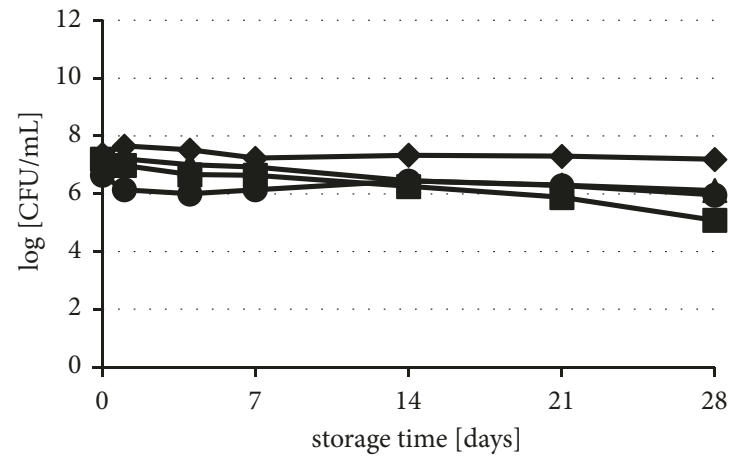

(b)

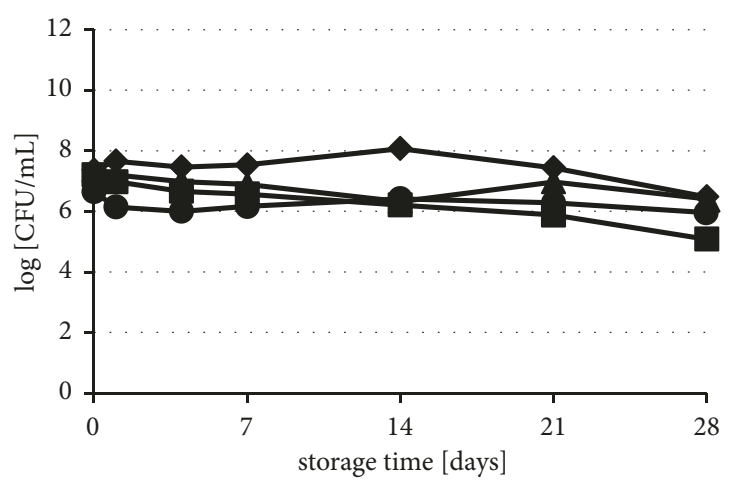

(d)

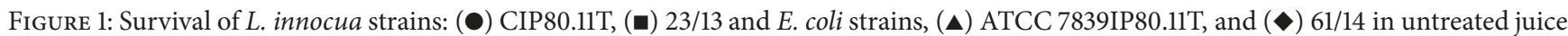
samples: (a) carrot juice stored at $5^{\circ} \mathrm{C}$, (b) beetroot juice stored at $5^{\circ} \mathrm{C}$, (c) carrot juice stored at $25^{\circ} \mathrm{C}$, and (d) beetroot juice stored at $25^{\circ} \mathrm{C}$, for up to 28 days.

by 1.8 and $3.3 \log$ depending on the strain. In turn, results obtained at $25^{\circ} \mathrm{C}$ had shown that amount of viable $E$. coli cells increased about $1.0 \log \mathrm{CFU} / \mathrm{mL}$, while significant differences were found for L. innocua. Survival rates of both L. innocua strains correlated negatively with temperature. The number of these bacteria drastically decreased, between 14 and 21 days of storage, at $25^{\circ} \mathrm{C}$. Monitoring of carrot juice $\mathrm{pH}$ (suspended with $L$. innocua strains) showed that this parameter decreased from 6.2 to 4.2 during 28 days of storage, while $\mathrm{pH}$ of carrot juice without bacteria was found stable for all time of storage $(6.18 \pm 0.04)$.

Patterson et al. (2012) have suggested that carrot juice is inherently detrimental to the growth of L. monocytogenes. They observed survivability of pathogenic bacteria in two variants of carrot juice control samples, during 10 days of storage at $4^{\circ} \mathrm{C}, 8^{\circ} \mathrm{C}$, and $12^{\circ} \mathrm{C}$. Both, heat and nonheat sterilized, carrot juice control samples were inoculated by cocktail of $L$. monocytogenes and then stored. Number of $L$. monocytogenes, suspended in nonheat carrot juice, decreased at refrigerated temperatures by $6.56 \log \mathrm{CFU} / \mathrm{mL}$ to 5.06 $\log \mathrm{CFU} / \mathrm{mL}$ and $6.00 \log \mathrm{CFU} / \mathrm{mL}$, respectively. In case of prior heat sterilized carrot juice, Listeria numbers increased during storage at all temperatures. Presumably, these differences are associated with thermal-sensitive properties of antimicrobial compounds in carrot juice (carrot juice of our studies was pasteurized). Additionally, authors had searched for influence of carrot juice properties on E. coli. Their results were similar to our findings. They observed that the number of $E$. coli in carrot juice remained constant, while juice was stored up to 14 days at $4^{\circ} \mathrm{C}$; however it increased during storage at $8^{\circ} \mathrm{C}$ and $12^{\circ} \mathrm{C}$. Moreover, heat treating of carrot juice prior to inoculation had no effect on growth on E. coli. The same results were achieved by Gómez Aldapa et al. (2013). It has been reported that the growth of the cocktail of diarrheagenic E. coli pathotype in carrot juice was inhibited at refrigerated temperature. After $24 \mathrm{~h}$ number of all diarrheagenic $E$. coli pathotypes increased during storage at $12^{\circ} \mathrm{C}, 20^{\circ} \mathrm{C}, 30^{\circ} \mathrm{C}$, and $37^{\circ} \mathrm{C}$. Some researchers had been trying to answer, how long pathogens would survive in acid juices if a contamination occurred [40-42]. Escherichia coli O157:H7 survived in pineapple juice ( $\mathrm{pH}$ 3.57) for 120 days in refrigerated temperature, but during ambient temperature storage, some decline in count was noted. In turn, avocado juice ( $\mathrm{pH}$ 6.2) supported growth of these bacteria at both temperatures [40]. Significant number of Listeria monocytogenes suspended in tomato juice survived during storage at $5^{\circ} \mathrm{C}$ and $30^{\circ} \mathrm{C}$ for 12 days; however counts of those bacteria slightly decreased in refrigerated temperature [41]. Oyarzábal et al. (2003) showed that Escherichia coli O157:H7, Listeria monocytogenes, and Salmonella were recoverable through 12 


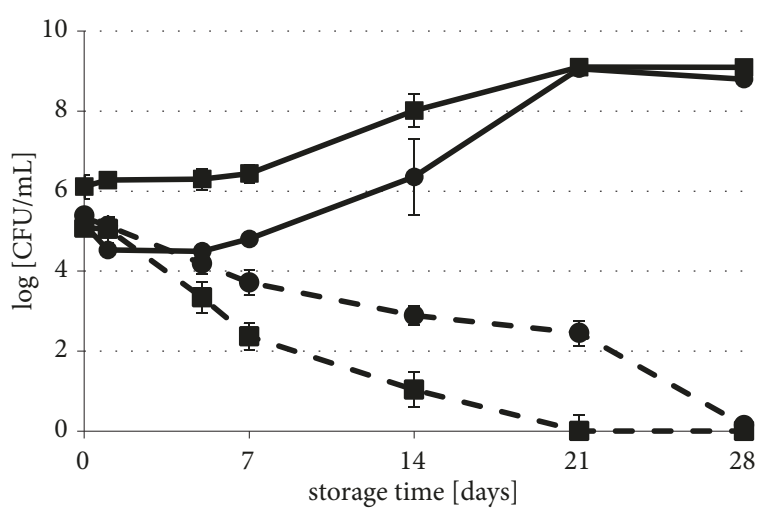

(a)

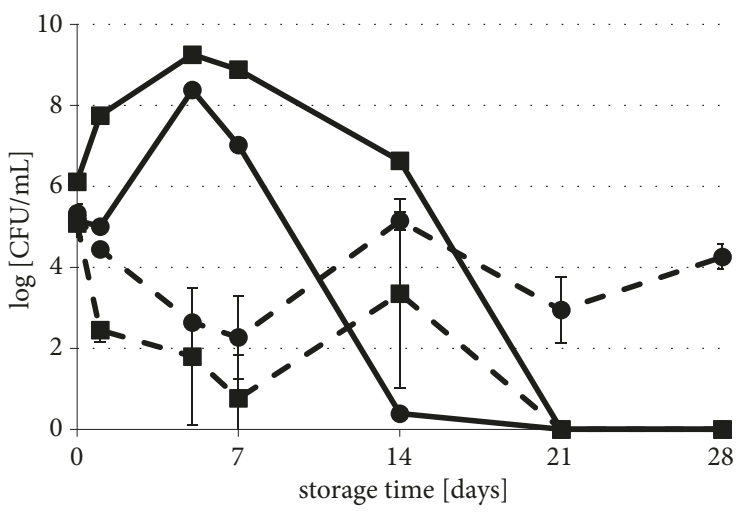

(b)

FiguRE 2: Survival of L. innocua strains in HHP treated carrot (-) and beetroot juice (----) stored at $5^{\circ} \mathrm{C}$ (a) and $25^{\circ} \mathrm{C}$ (b) for up to 28 days. $L$. innocua (๑) CIP80.11T and (घ) L. innocua 23/13. HHP sublethal treatment conditions for each strain are in Table 1. The error bars represent the standard deviation of measurements for 2 samples in two separate sample runs. Limit of detection was $1 \log C F U / \mathrm{mL}$.

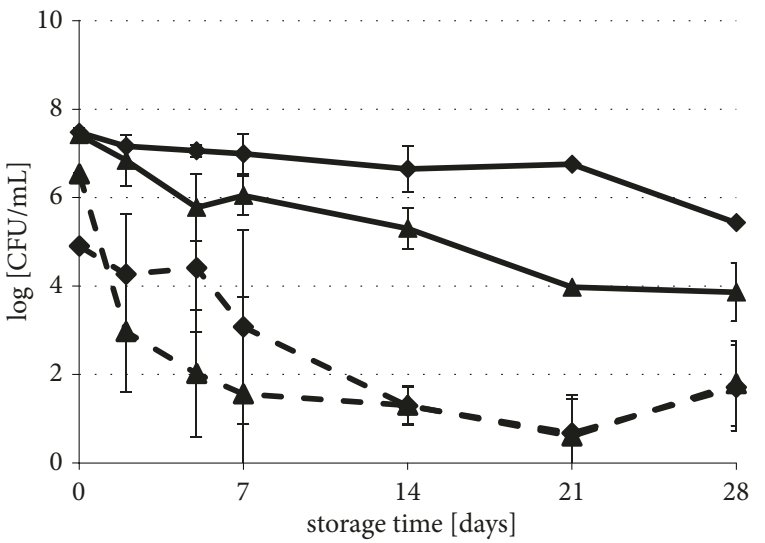

(a)

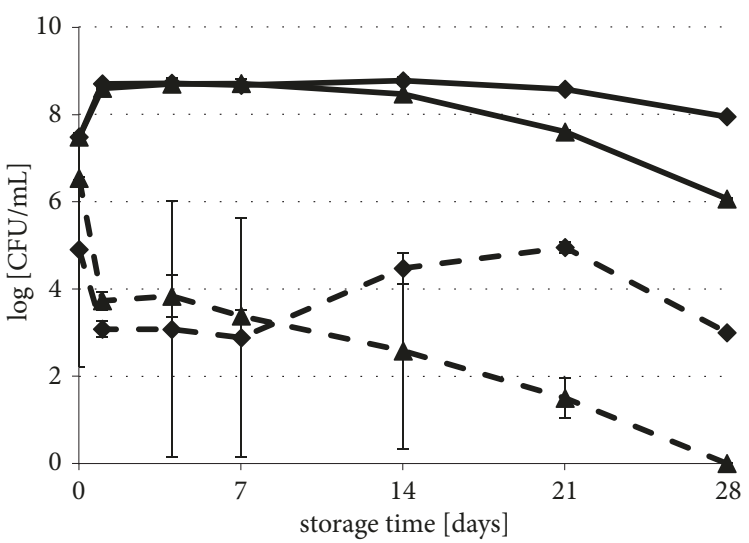

(b)

Figure 3: Survival of E. coli strains in HHP treated carrot (-) and beetroot juice (----) stored at $5^{\circ} \mathrm{C}$ (a) and $25^{\circ} \mathrm{C}$ (b) for up to 28 days. E. coli ATCC 7839IP80.11T $(\boldsymbol{\Delta})$ and E. coli 61/14 $(\diamond)$. HHP sublethal treatment conditions for each strain are in Table 1. The error bars represent the standard deviation of measurements for 2 samples in two separate sample runs. Limit of detection was $1 \log$ CFU/mL.

weeks of storage at $-23^{\circ} \mathrm{C}$ in apple, orange, pineapple, and white grape juice concentrates $(\mathrm{pH}$ 3.6-3.7) and banana puree ( $\mathrm{pH}$ 5.5).

\subsection{Effect of Long-Term Storage and Temperature on Survival} and Regeneration of HHP-Sublethally Injured E. coli and L. innocua in Vegetable Juices. The impact of long-term storage on the survival of HHP-injured bacterial strains, in carrot and beetroot juices, is shown in Figures 2 and 3 . Survival rates of L. innocua in carrot juice during 4-week refrigerated storage were similar to both collection and wild type strain (Figure 2(a)). It was observed that the number of the bacterial population significantly increased, by 3.64 $\log \mathrm{CFU} / \mathrm{ml}$ and $2.98 \log \mathrm{CFU} / \mathrm{ml}$, respectively, in reference to initial HHP-treated viable cell counts. In beetroot juice, the reduction of the L. innocua cells in the population was noticed (Figure 2(a)). On the 21st day of storage, cells of the wild type strain were not detected. A week later, the collection strain was also below the detection level $(1.0 \log \mathrm{CFU} / \mathrm{mL})$. $E$. coli growth during long-term refrigerated storage was not observed, neither in carrot juice nor in beetroot juice (Figure 3(a)). However, the progress of the cell reduction in the population was noticeably faster in beetroot juice during 4-week refrigerated storage. The number of the E. coli cells of collection and wild type strain in populations decreased. In the case of carrot juice, the decrease was 3.57 and 2.05 $\log \mathrm{CFU} / \mathrm{ml}$. When it comes to beetroot juice, the decrease was 5.42 and $3.19 \log \mathrm{CFU} / \mathrm{ml}$, in reference to initial microbial counts, just after HHP treatment. The E. coli population in beetroot juice accomplished nearly $1.0 \log \mathrm{CFU} / \mathrm{mL}$ after 21 days of refrigerated storage. However, extending the storage time to 4 weeks showed microbial growth of these bacteria.

The number of L. innocua in the population increased by over $3.0 \log \mathrm{CFU} / \mathrm{mL}$ during the 4 days of storage of carrot juice at $25^{\circ} \mathrm{C}$ (Figure 2(b)). The subsequent storage resulted in the rapid decrease of the amount of these bacteria in samples. After the 3-week period, the growth was not 
TABLE 2: Results of the growth potential.

\begin{tabular}{|c|c|c|c|c|}
\hline Type of sample & & Time [days of storage] & $\log \mathrm{CFU} / \mathrm{mL}$ & growth potential $(\delta)$ \\
\hline \multirow{8}{*}{ Carrot juice stored at $5^{\circ} \mathrm{C}$} & \multirow{2}{*}{$\begin{array}{c}\text { Listeria innocua } \\
\text { CIP 80.11T }\end{array}$} & $\mathrm{T}=0$ & 5,16 & \multirow{2}{*}{3,65} \\
\hline & & $\mathrm{T}=28$ & 8,82 & \\
\hline & \multirow{4}{*}{$\begin{array}{c}\text { Listeria } \\
\text { innocua-wild type } \\
\text { strain } 23 / 13 \\
\text { Escherichia coli } \\
\text { ATCC } 7839\end{array}$} & $\mathrm{~T}=0$ & 6,12 & \multirow{2}{*}{2,98} \\
\hline & & $\mathrm{T}=28$ & 9,10 & \\
\hline & & $\mathrm{T}=0$ & 7,42 & \multirow{2}{*}{$-3,56$} \\
\hline & & $\mathrm{T}=28$ & 3,86 & \\
\hline & \multirow{2}{*}{$\begin{array}{l}\text { Escherichia coli -wild } \\
\text { type strain } 61 / 14\end{array}$} & $\mathrm{~T}=0$ & 7,48 & \multirow{2}{*}{$-2,05$} \\
\hline & & $\mathrm{T}=28$ & 5,43 & \\
\hline \multirow{8}{*}{ Beetroot juice stored at $5^{\circ} \mathrm{C}$} & \multirow{2}{*}{$\begin{array}{l}\text { Listeria innocua } \\
\text { CIP } 80.11 \mathrm{~T}\end{array}$} & $\mathrm{~T}=0$ & 5,37 & \multirow{2}{*}{$-5,37$} \\
\hline & & $\mathrm{T}=28$ & 0,00 & \\
\hline & \multirow{4}{*}{$\begin{array}{c}\text { Listeria } \\
\text { innocua-wild type } \\
\text { strain } 23 / 13 \\
\text { Escherichia coli } \\
\text { ATCC } 7839\end{array}$} & $\mathrm{~T}=0$ & 5,15 & \multirow{2}{*}{$-5,15$} \\
\hline & & $\mathrm{T}=28$ & 0,00 & \\
\hline & & $\mathrm{T}=0$ & 6,53 & \multirow{2}{*}{$-4,35$} \\
\hline & & $\mathrm{T}=28$ & 2,18 & \\
\hline & \multirow{2}{*}{$\begin{array}{l}\text { Escherichia coli -wild } \\
\text { type strain } 61 / 14\end{array}$} & $\mathrm{~T}=0$ & 6,50 & \multirow{2}{*}{$-3,38$} \\
\hline & & $\mathrm{T}=28$ & 3,11 & \\
\hline \multirow{8}{*}{ Carrot juice stored at $25^{\circ} \mathrm{C}$} & \multirow{2}{*}{$\begin{array}{c}\text { Listeria innocua } \\
\text { CIP 80.11T }\end{array}$} & $\mathrm{T}=0$ & 5,16 & \multirow{2}{*}{$-5,16$} \\
\hline & & $\mathrm{T}=28$ & 0,00 & \\
\hline & \multirow{4}{*}{$\begin{array}{c}\text { Listeria } \\
\text { innocua-wild type } \\
\text { strain } 23 / 13 \\
\text { Escherichia coli } \\
\text { ATCC } 7839\end{array}$} & $\mathrm{~T}=0$ & 6,12 & \multirow{2}{*}{$-6,12$} \\
\hline & & $\mathrm{T}=28$ & 0,00 & \\
\hline & & $\mathrm{T}=0$ & 7,48 & \multirow{2}{*}{$-1,42$} \\
\hline & & $\mathrm{T}=28$ & 6,06 & \\
\hline & \multirow{2}{*}{$\begin{array}{l}\text { Escherichia coli-wild } \\
\text { type strain } 61 / 14\end{array}$} & $\mathrm{~T}=0$ & 7,48 & \multirow{2}{*}{0,46} \\
\hline & & $\mathrm{T}=28$ & 7,94 & \\
\hline \multirow{8}{*}{ Beetroot juice stored at $5^{\circ} \mathrm{C}$} & \multirow{2}{*}{$\begin{array}{c}\text { Listeria innocua } \\
\text { CIP } 80.11 \mathrm{~T}\end{array}$} & $\mathrm{~T}=0$ & 5,37 & \multirow{2}{*}{$-1,06$} \\
\hline & & $\mathrm{T}=28$ & 4,31 & \\
\hline & \multirow{4}{*}{$\begin{array}{c}\text { Listeria } \\
\text { innocua-wild type } \\
\text { strain } 23 / 13 \\
\text { Escherichia coli } \\
\text { ATCC } 7839\end{array}$} & $\mathrm{~T}=0$ & 5,15 & \multirow{2}{*}{$-5,15$} \\
\hline & & $\mathrm{T}=28$ & 0,00 & \\
\hline & & $\mathrm{T}=0$ & 6,53 & \multirow{2}{*}{$-6,53$} \\
\hline & & $\mathrm{T}=28$ & 0,00 & \\
\hline & Escherichia coli-wild & $\mathrm{T}=0$ & 6,50 & -3.50 \\
\hline & type strain $61 / 14$ & $\mathrm{~T}=28$ & 3,00 & \\
\hline
\end{tabular}

The growth potential $(\delta)$ is the difference between the log at the end of shelf life and the log of the initial concentration.

Criteria:

$\delta>0.5 \log \mathrm{CFU} / \mathrm{mL}$, growth of bacteria possible.

$\delta \leq 0.5 \log \mathrm{CFU} / \mathrm{mL}$, growth of bacteria impossible.

observed. Growth of E. coli was noticed, only in the first 48th h of storage at $25^{\circ} \mathrm{C}$ (Figure 3(b)). During the next 12 days of storage, survival of $E$. coli strains in HHP, carrot juice was found stable and reached about $9 \log \mathrm{CFU} / \mathrm{mL}$. However, after that time, the population of the wild type strain slightly decreased by $2.40 \log \mathrm{CFU} / \mathrm{mL}$ (Figure 3(b)). The number of $L$. innocua cells in the population decreased after 7 days of beetroot juice storage at $25^{\circ} \mathrm{C}$ (Figure 2(b)). Extension of the storage time caused unitary spoilage of this product. On the last day of storage, the number of $L$. innocua collection strain cells reached to $4.26 \log \mathrm{CFU} / \mathrm{mL}$, while the number of wild type strains was under the detection limit. The opposite phenomenon was observed with E. coli (Figure 3(b)). The number of collection strains in HHP-beetroot juice was under $1.0 \log \mathrm{CFU} / \mathrm{mL}$, at the end of the period of storage at $25^{\circ} \mathrm{C}$. During the same storage conditions, E. coli wild type strain increased and reached $3.0 \log \mathrm{CFU} / \mathrm{mL}$ on the 28th day. The results of the growth potential $(\delta)$ are shown in Table 2. Only in the case of L. innocua strains in carrot juice, stored at $5^{\circ} \mathrm{C}$, the growth potential was above $0.5 \log \mathrm{CFU} / \mathrm{mL}$. This result means that the carrot juice supported growth of $L$. innocua, which was stored at refrigerated conditions. In other juice samples, the value of bacterial growth potential was less than the critical value. Hence, these conditions retard the propagation of tested strains.

The changes of sublethal injuries of bacterial cells in vegetable juices, during long-term storage at $5^{\circ} \mathrm{C}$ and $25^{\circ} \mathrm{C}$, are shown in Tables 3 and 4, respectively. Initial levels 


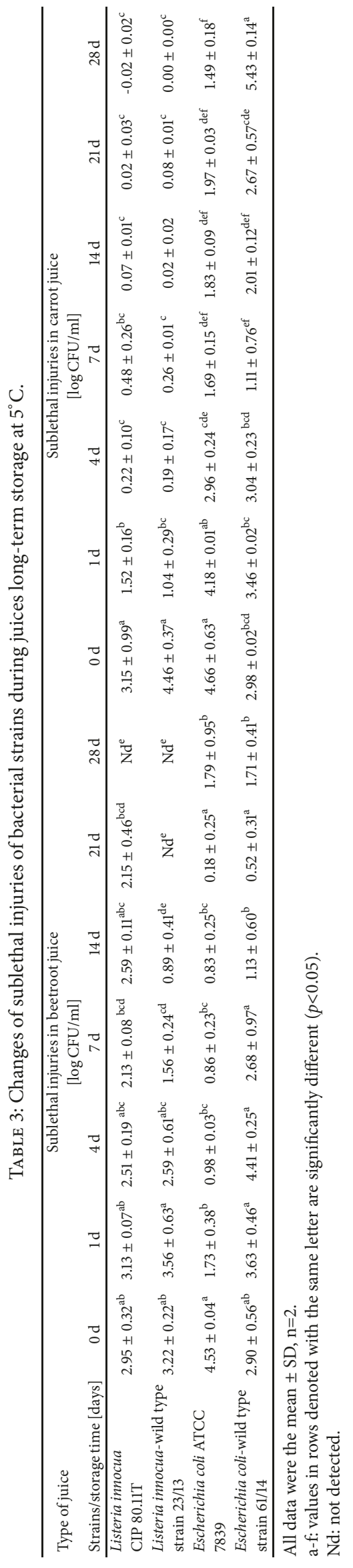




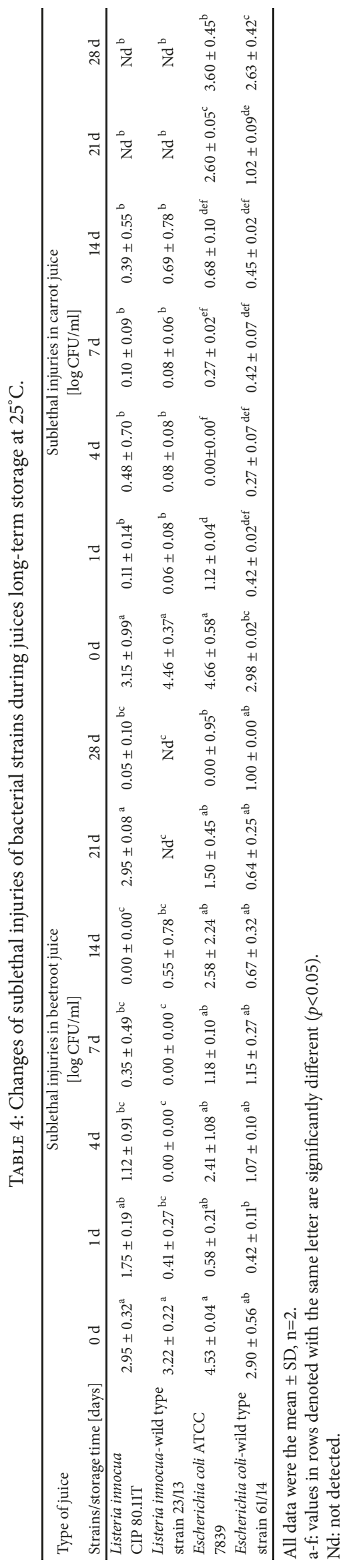


of sublethal injury of the strains, after HHP treatment, were 2.9-4.5 $\log \mathrm{CFU} / \mathrm{ml}$. The regeneration of sublethally injured cells suspended in carrot juice was observed. The regeneration of $L$. innocua after the first day of storage at $5^{\circ} \mathrm{C}$ (Table 3) and at $25^{\circ} \mathrm{C}$ (Table 4) was significant. The number of injured cells of E.coli collection strain significantly decreased $(p<0.05)$, up to the 7 th day of refrigerated storage. Thereafter, some differences in the number of sublethally injured cells were found, although they were not statistically significant $(p \geq 0.05)$. Up to the first 7 days of storage, the regeneration of sublethally injured cells of wild type E. coli was also observed. Extending the storage time resulted in the gradual increase in the number of injured cells of wild type E. coli. At the 28th day of storage, the level of injured cells reached about doubled $(5.43 \log \mathrm{CFU} / \mathrm{mL})$. Decreasing tendency of sublethal injury of $E$. coli, during storage of the HHP-carrot juice at $25^{\circ} \mathrm{C}$, was also observed. This phenomenon was much faster, than at $5^{\circ} \mathrm{C}$ (Table 4). After 24 hours of storage, the number of regenerated cells of collection strain was $0.48 \log \mathrm{CFU} / \mathrm{mL}$ at $5^{\circ} \mathrm{C}$ and $3.54 \log \mathrm{CFU} / \mathrm{mL}$ at $25^{\circ} \mathrm{C}$. In most instances, there was no significant cells recovery, during long-term refrigerated storage for all strains in beetroot juice (Table 3). However, the number of sublethally injured cells decreased with in view of bacterial population dying (Figures 2(a) and $3(\mathrm{a})$ ). Long-term storage of beetroot juice at $25^{\circ} \mathrm{C}$ showed that recovery of injured pathogen cells may occur, albeit spoiling of this product intermittently occurred (Table 4 , Figures 2 (b) and 3(b)).

Alkaline $\mathrm{pH}$ matrices have shown that it is incredibly challenging, to achieve microbial decontamination by HHP [20]. Despite the belief that HHP technology is intended for acid products, scientific researchers are still searching for the application of high pressure on this kind of matrices $[6,24,25,43]$. Similarly to our study, Patterson et al. (2012) observed that the population of HHP-injured E. coli (500 MPa, $1 \mathrm{~min}$.) had decreased during subsequent storage of carrot juice. Just after pressure treatment, inactivation was $1.82 \log \mathrm{CFU} / \mathrm{mL}$, while by day 10 , the number of these bacteria reached undetectable levels, independent from the storage temperature. The same HHP condition inactivated cocktail of L. monocytogenes in carrot juice. During the 14 days of storage at any temperature, it remained below the limit of detection. The study of injury induced by HHP in microorganisms and subsequent recovery in fruit juices has been reported by several groups of researchers [21, 22, 34, $44,45]$. So far, the pressure-induced injured microorganisms in beetroot juice have been reported in few publications [31, 46-48]. Unfortunately, there is small data about the influence of storage. Buzrul et al. (2008) used mild HHP ( $350 \mathrm{MPa}$ for $5 \mathrm{~min}$.) to inactivate Escherichia coli and Listeria innocua in kiwifruit ( $\mathrm{pH} 3.32$ ) and pineapple juice ( $\mathrm{pH}$ 3.77). They investigate the effect of storage on the survival of these microorganisms, in above mentioned juices, at different temperatures $\left(4^{\circ} \mathrm{C}, 20^{\circ} \mathrm{C}, 37^{\circ} \mathrm{C}\right)$. Inactivation increased more than $1.0 \log \mathrm{CFU} / \mathrm{mL}$, during storage at $4^{\circ} \mathrm{C}$ for $24 \mathrm{~h}$, for both bacteria in both juices. During subsequent 3 weeks of storage, at all tested temperatures, no injury recovery was detected in both juices. The same phenomenon was observed by Jordan et al. (2001) for E. coli in orange, tomato, and apple juices.
Lots of studies confirmed that natural microbiota of HHP-treated vegetable juices may recover during storage. Picouet et al. (2015) monitored that three microbial groups were recovered, between 7 th and 21st days of refrigerated storage, in HHP-treated carrot juice under $600 \mathrm{MPa}$ for $5 \mathrm{~min}$. Despite that, the total anaerobes bacteria remained below the detection limit in the first week of storage. On day 21, these bacteria reached $1.2 \log \mathrm{CFU} / \mathrm{mL}$ in nonacidified $(\mathrm{pH}$ 6.48) and $4.3 \log \mathrm{CFU} / \mathrm{mL}$ in acidified (pH 5.5) juice. In turn, yeast and molds counts reached an amount equal to or below $3.0 \log \mathrm{CFU} / \mathrm{mL}$. The authors concluded that acidification of carrot juice did not advantageously extend the shelf life of the product. Zhang et al. (2016) showed that indigenous microbiota of carrot juice, preserved by HHP (550 MPa, 6 min.), slightly increased after 20 days of storage at refrigerated temperature. Similarly to aforementioned, Patterson et al. (2012) observed that HHP-injured natural microbiota of carrot juice (500 and $600 \mathrm{MPa}, 1 \mathrm{~min}$ ) recovered faster at $12^{\circ} \mathrm{C}(7 \log \mathrm{CFU} / \mathrm{mL}$ at the 10 th day of storage), rather than at $4^{\circ} \mathrm{C}(3 \log \mathrm{CFU} / \mathrm{mL}$ at the $22 \mathrm{nd}$ day of storage). Moreover, they noticed that pressure treatment, significantly delayed the recovery and growth of the surviving microorganisms, in reference to untreated juice sample. Sokołowska et al. (2014a) observed that total count of spoilage microorganism in HHP-beetroot juice (400 MPa, $10 \mathrm{~min}$ ) was unchanged for 10 days of refrigerated storage. Then, there was an increase of contamination to more than $3.0 \log \mathrm{CFU} / \mathrm{mL}$. In turn, indigenous microbiota in fruit juices normally had been not recovered during long-term storage, even if juice was preserved by mild-HHP treatment $[49,50]$. Kimura et al. (2017) observed that the degree of damage by HHP may differ cell-by-cell, and oxidative stress may continue after HHP treatment. Depending on the storage environment, resuscitation and recovered cells may multiply, before other injured cells complete resuscitation. Microbial cells, surviving pressurization, also became sublethally injured and developed sensitivity to environments, which the normal cells were resistant to [51].

The new edition of ISO 11290-1:2017 Microbiology of the food chain-Horizontal method for the detection and enumeration of Listeria monocytogenes and of Listeria spp.-Part 1: Detection method, does not take into consideration resuscitation step. From human's health safety point of view it may be risky decision, especially due to the fact that systematic (invasive) form of listeriosis is now recognized as occurring more frequently in small outbreaks than previously recognized [52]. Due to the fact that injured bacterial cells display limited possibility, or even inability to grow on selective agars, and due to the above-mentioned fact, sublethally injured cells should require additional attention to quality control sectors of food operators. This aspect needs especially better understanding, in case if products are preserved by nonthermal alternative technologies, by virtue of induction of sublethal injuries. The Codex Alimentarius Commission (CAC) proposed the following criterion to characterize food products that support L. monocytogenes growth. As it was written in CAC: "a RTE food in which there is a greater than average of $0.5 \mathrm{log}$ increase in the level of the organism, for at least the expected shelf life (as labeled by the manufacturer) 
under reasonably foreseeable conditions of distribution, storage and use to consumption, including a safety margin" (CAC, 2009). Processed and ready-to-eat (RTE) foods with a prolonged shelf life under refrigeration are at risk products for listeriosis [40]. Uyttendaele et al. (2009) observed the growth of L. monocytogenes in three types of ready-to-eat products, stored under refrigerated temperature in challenge testing. They suggest that whether a food supports the growth of L. monocytogenes, or not is mainly determined by the physicochemical factors ( $\mathrm{pH}, \mathrm{a}_{\mathrm{w}}$, packaging atmosphere) of the food matrix, rather than being defined as such by the food type.

\section{Conclusion}

The results of this study indicate that carrot juice supports growth and regeneration of HHP-sublethally injured $L$. innocua. Based on the above data, HHP-treated beetroot juice can be classified as a safe product, while carrot juice may be classified as a high risk food. Our results confirmed that HHP-treated vegetable juices need to be kept in refrigerated conditions. However, more scientific studies need to be conducted to find an understanding of the bacterial mechanisms, involved in cell recovery during storage in food matrices.

Predictive microbiology is a useful method to help estimate food safety and shelf life of product, having established the foods' intrinsic and extrinsic characteristics. However, good manufacturing practices (GMP), hygiene practices (GHP), the development, and implementation of procedures, based on HACCP, are fundamental in maintaining food safety, the setting, and validating of food shelf life.

\section{Data Availability}

The data used to support the findings of this study are available from the corresponding author upon request.

\section{Ethical Approval}

Ethical clearance was not required and was not necessary for this study.

\section{Conflicts of Interest}

The authors declare that there are no conflicts of interest regarding the publication of the article.

\section{Acknowledgments}

This work was supported by the Prof. Wacław Dąbrowski Institute of Agricultural and Food Biotechnology.

\section{References}

[1] G. J. Kapadia, M. A. Azuine, R. Sridhar et al., "Chemoprevention of DMBA-induced UV-B promoted, NOR-1-induced TPA promoted skin carcinogenesis, and DEN-induced phenobarbital promoted liver tumors in mice by extract of beetroot," Pharmacological Research, vol. 47, no. 2, pp. 141-148, 2003.
[2] Z. Pietrzkowski, B. Nemzer, A. Sp et al., "Influence of betalain-rich extract on reduction of discomfort associated with osteoarthritis," New Medicin, vol. 1, pp. 12-17, 2010.

[3] T. Clifford, G. Howatson, D. J. West, and E. J. Stevenson, “The potential benefits of red beetroot supplementation in health and disease," Nutrients, vol. 7, no. 4, pp. 2801-2822, 2015.

[4] I. Domagała-Światkiewicz and M. Gastoł, "Comparative study on mineral content of organic and conventional carrot, celery and red beet juices," Acta Scientiarum Polonorum, Hortorum Cultus, vol. 11, no. 2, pp. 173-183, 2012.

[5] "USDA Food composition Databases," https://ndb.nal.usda .gov/ndb/search/list_28.02.2018.

[6] S. Zhu, C. Wang, H. S. Ramaswamy, and Y. Yu, "Phase transitions during high pressure treatment of frozen carrot juice and influence on Escherichia coli inactivation," LWT_Food Science and Technology, vol. 79, pp. 119-125, 2017.

[7] J. Czapski, K. Mikołajczyk, and M. Kaczmarek, "Relationship between antioxidant capacity of red beet juice and contents of its betalain pigments," Polish Journal of Food and Nutrition Sciences, vol. 59, no. 2, pp. 119-122, 2009.

[8] J. Wruss, G. Waldenberger, S. Huemer et al., "Compositional characteristics of commercial beetroot products and beetroot juice prepared from seven beetroot varieties grown in Upper Austria," Journal of Food Composition and Analysis, vol. 42, pp. 46-55, 2015.

[9] C. Alklint, L. Wadsö, and I. Sjöholm, "Effects of modified atmosphere on shelf-life of carrot juice," Food Control, vol. 15, no. 2, pp. 131-137, 2004.

[10] G. M. Sapers, "Washing and sanitizing raw materials for minimally processed fruit and vegetable products," in Microbial Safety of Minimally Processed Foods, J. S. Novak, G. M. Sapers, and V. K. Juneja, Eds., pp. 221-253, CRC Press, Boca Raton, Fla, USA, 2003.

[11] B. Sokolowska, M. Chotkiewicz, J. Niezgoda, A. Dekowska, and B. Sokołowska, "Evaluation of microbial contamination of commercially available unpasteurized, freshly squeezed fruit and vegetable juices," Zeszyty Problemowe Postępów Nauk Rolniczych, vol. 569, pp. 219-228, 2011.

[12] M. Fonberg-Broczek, B. Windyga, G. Prestamo, H. Sciezynska, A. Grochowska, and K. Grecka, "Application of high pressure processing (HPP) for pasteurisation of fresh squizzed juices," Bromat. Chem. Toksykol suplement, pp. 129-133, 2006.

[13] M. D. R. Torres-Vitela, C. A. Gómez Aldapa, J. F. Cerna-Cortes, A. Villarruel-López, E. Rangel-Vargas, and J. Castro-Rosas, "Presence of indicator bacteria, diarrhoeagenic Escherichia coli pathotypes and Salmonella in fresh carrot juice from Mexican restaurants," Letters in Applied Microbiology, vol. 56, no. 3, pp. 180-185, 2013.

[14] Z. Libudzisz, K. Kowal, and Z. Zakowska, "Technical microbiology, Microorganisms in biotechnology, environmental protection and food production" (Polish), Wydawnictwo Naukowe PWN, t. II, pp. 235-288, 2008.

[15] D. C. Machado, C. M. Maia, I. D. Carvalho, N. F. Da Silva, M. C. Dantas Porfírio Borges Andre, and Á. B. Serafini, "Microbiological quality of organic vegetables produced in soil treated with different types of manure and mineral fertilizer," Brazilian Journal of Microbiology, vol. 37, no. 4, pp. 538-544, 2006.

[16] K. Jones and J. Heaton, "Microbial contamination of fruit and vegetables," The Magazine of Health Protection Agency, vol. 7, pp. 28-31, 2007.

[17] K. R. Aneja, R. Dhiman, N. K. Aggarwal, V. Kumar, and M. Kaur, "Microbes associated with freshly prepared juices of citrus and 
carrots," International Journal of Food Science, vol. 2014, Article ID 408085, 7 pages, 2014.

[18] J. W. Buck, R. R. Walcott, and L. R. Beuchat, "Recent trends in microbiological safety of fruits and vegetables," Plant Health Progress, vol. 4, no. 1, p. 25, 2003.

[19] H.-W. Huang, S.-J. Wu, J.-K. Lu, Y.-T. Shyu, and C.-Y. Wang, "Current status and future trends of high-pressure processing in food industry," Food Control, vol. 72, pp. 1-8, 2017.

[20] D. F. Farkas, "A short history of research and development efforts leading to the commercialization of high-pressure processing of foods," in High Pressure Processing of Food, V. M. Balasubramaniam, G. V. Barbosa-Cánovas, and H. L. M. Lelieveld, Eds., pp. 19-36, Principles, technology and applications, Springer, New York, NY, USA, 2016.

[21] S. Buzrul, H. Alpas, A. Largeteau, and G. Demazeau, "Inactivation of Escherichia coli and Listeria innocua in kiwifruit and pineapple juices by high hydrostatic pressure," International Journal of Food Microbiology, vol. 124, no. 3, pp. 275-278, 2008.

[22] A. Bayindirli, H. Alpas, F. Bozoglu, and M. Hizal, "Efficiency of high pressure treatment on inactivation of pathogenic microorganisms and enzymes in apple, orange, apricot and sour cherry juices," Food Control, vol. 17, no. 1, pp. 52-58, 2006.

[23] P. A. Picouet, C. Sárraga, S. Cofán, N. Belletti, and M. Dolors Guàrdia, "Effects of thermal and high-pressure treatments on the carotene content, microbiological safety and sensory properties of acidified and of non-acidified carrot juice," $L W T$ Food Science and Technology, vol. 62, no. 1, pp. 920-926, 2015.

[24] W. Żyngiel and J. Kolenda, "The influence of high pressure processing parameters on quality and stability of preserved carrot juices," Bromatologia i Chemia Toksykologiczna, pp. 408413, 2009.

[25] Y. Zhang, X. Liu, Y. Wang, F. Zhao, Z. Sun, and X. Liao, "Quality comparison of carrot juices processed by high-pressure processing and high-temperature short-time processing," Innovative Food Science \& Emerging Technologies, vol. 33, pp. 135-144, 2016.

[26] H.-W. Huang, H.-M. Lung, B. B. Yang, and C.-Y. Wang, "Responses of microorganisms to high hydrostatic pressure processing," Food Control, vol. 40, no. 1, pp. 250-259, 2014.

[27] M. F. Patterson, M. Quinn, R. Simpson, and A. Gilmour, "Sensitivity of vegetative pathogens to high hydrostatic pressure treatment in phosphate-buffered saline and foods," Journal of Food Protection, vol. 58, no. 5, pp. 524-529, 1995.

[28] C.-Y. Wang, H.-W. Huang, C.-P. Hsu, and B. B. Yang, "Recent advances in food processing using high hydrostatic pressure technology," Critical Reviews in Food Science and Nutrition, vol. 56, no. 4, pp. 527-540, 2016.

[29] L. Espina, D. García-Gonzalo, and R. Pagán, "Detection of thermal sublethal injury in Escherichia coli via the selective medium plating technique: mechanisms and improvements," Frontiers in Microbiology, vol. 30, no. 7, p. 1376, 2016.

[30] B. Yang, Y. Shi, X. Xia et al., "Inactivation of foodborne pathogens in raw milk using high hydrostatic pressure," Food Control, vol. 28, no. 2, pp. 273-278, 2012.

[31] B. Sokołowska, S. Skapska, J. Niezgoda, M. Rutkowska, A. Dekowska, and S. J. Rzoska, "Inactivation and sublethal injury of Escherichia coli and Listeria innocua by high hydrostatic pressure in model suspensions and beetroot juice," High Pressure Research, vol. 34, no. 1, pp. 147-155, 2014.

[32] N. G. Besse, "Influence of various environmental parameters and of detection procedures on the recovery of stressed L. monocytogenes: A review," Food Microbiology, vol. 19, no. 2-3, pp. 221-234, 2002.
[33] A. M. Wesche, J. B. Gurtler, B. P. Marks, and E. T. Ryser, "Stress, sublethal injury, resuscitation, and virulence of bacterial foodborne pathogens," Journal of Food Protection, vol. 72, no. 5, pp. 1121-1138, 2009.

[34] M. Linton, J. M. J. McClements, and M. F. Patterson, "Survival of Escherichia coli O157:H7 during storage in pressure-treated orange juice," Journal of Food Protection, vol. 62, no. 9, pp. 10381040, 1999.

[35] European Commission Regulation (EC) No 2073/2005 of 15 November 2005 on microbiological criteria for foodstuffs, 2005.

[36] Guidance Note No. 18, Validation of product shelf-life, Revision 3, Food Safety Authority of Ireland, 2017.

[37] A. Serraino and F. Giacometti, "Introduction to challenge test and microbiological characterisation of local products," Italian Journal of Food Safety, vol. 3, no. 1, pp. 34-35, 2014.

[38] J. Nasiłowska, B. Sokołowska, and M. Fonberg-Broczek, "The impact of high hydrostatic pressure on inactivation and sublethal injury of foodborne pathogenes in beetroot juice," Postępy Nauki i Technologii Przemystu Rolno-Spożywczego, vol. 71, no. 1, pp. 21-27, 2016.

[39] J. Nasiłowska, B. Sokołowska, and M. Fonberg-Broczek, "The behaviour of Listeria innocua strains under pressure treatment - inactivation and sublethal injury," Polish Journal of Food and Nutrition Sciences, 2018.

[40] I. Mutaku, W. Erku, and M. Ashenafi, "Growth and survival of Escherichia coli O157:H7 in fresh tropical fruit juices at ambient and cold temperatures," International Journal of Food Sciences and Nutrition, vol. 56, no. 2, pp. 133-139, 2005.

[41] I. Diakogiannis, C. Proestos, T. Varzakas, and P. Markaki, "Survival of Listeria Monocytogenes in Tomato Juice at 5 and 30॰C Storage," Current Research in Nutrition and Food Science Journal, vol. 5, no. 1, pp. 01-05, 2017.

[42] O. A. Oyarzábal, M. C. L. Nogueira, and D. E. Gombas, "Survival of E. coli O157:H7, Listeria monocytogenes, and Salmonella in juice concentrates," Journal of Food Protection, vol. 66, no. 9, pp. 1595-1598, 2003.

[43] M. F. Patterson, A. M. McKay, M. Connolly, and M. Linton, "The effect of high hydrostatic pressure on the microbiological quality and safety of carrot juice during refrigerated storage," Food Microbiology, vol. 30, no. 1, pp. 205-212, 2012.

[44] S. L. Jordan, C. Pascual, E. Bracey, and B. M. Mackey, "Inactivation and injury of pressure-resistant strains of Escherichia coli O157 and Listeria monocytogenes in fruit juices," Journal of Applied Microbiology, vol. 91, no. 3, pp. 463-469, 2001.

[45] C. Garcia-Graells, K. J. A. Hauben, and C. W. Michiels, "Highpressure inactivation and sublethal injury of pressure-resistant Escherichia coli mutants in fruit juices," Applied and Environmental Microbiology, vol. 64, no. 4, pp. 1566-1568, 1998.

[46] B. Sokołowska, S. Skapska, M. Fonberg-Broczek et al., "The effect of high hydrostatic pressure on the survival of Saccharomyces cerevisiae in model suspensions and beetroot juice," High Pressure Research, vol. 33, no. 1, pp. 165-171, 2013.

[47] B. Sokołowska, S. Skąpska, M. Fonberg-Broczek et al., "The impact of high hydrostatic pressure (HHP) on native microflora and the color of beetroot juice - a preliminary shelf-life study," in Industrial, Medical and Environmental Applications of Microorganisms: Current Status and Trends, A. Mendez-Vilas, Ed., vol. 33, pp. 380-384, Academic Publisher, Wageningen, Netherlands, 2014.

[48] B. Sokołowska, Ł. Woźniak, S. Skąpska, I. Porębska, J. Nasiłowska, and S. J. Rzoska, "Evaluation of quality changes of 
beetroot juice after high hydrostatic pressure processing," High Pressure Research, vol. 37, no. 2, pp. 214-222, 2017.

[49] E. Varela-Santos, A. Ochoa-Martinez, G. Tabilo-Munizaga et al., "Effect of high hydrostatic pressure (HHP) processing on physicochemical properties, bioactive compounds and shelf-life of pomegranate juice," Innovative Food Science and Emerging Technologies, vol. 13, pp. 13-22, 2012.

[50] E. Juarez-Enriquez, I. Salmeron-Ochoa, N. Gutierrez-Mendez, H. S. Ramaswamy, and E. Ortega-Rivas, "Shelf life studies on apple juice pasteurised by ultrahigh hydrostatic pressure," $L W T$ Food Science and Technology, vol. 62, no. 1, pp. 915-919, 2015.

[51] H. Alpas, N. Kalchayanand, F. Bozoglu, and B. Ray, "Interactions of high hydrostatic pressure, pressurization temperature and $\mathrm{pH}$ on death and injury of pressure-resistant and pressuresensitive strains of foodborne pathogens," International Journal of Food Microbiology, vol. 60, no. 1, pp. 33-42, 2000.

[52] R. L. Buchanan, L. G. M. Gorris, M. M. Hayman, T. C. Jackson, and R. C. Whiting, "A review of Listeria monocytogenes: An update on outbreaks, virulence, dose-response, ecology, and risk assessments," Food Control, vol. 75, pp. 1-13, 2017. 


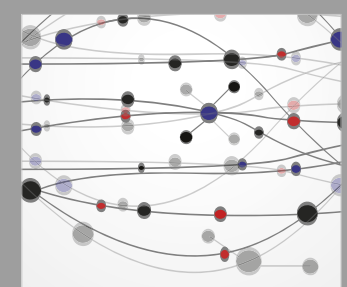

The Scientific World Journal
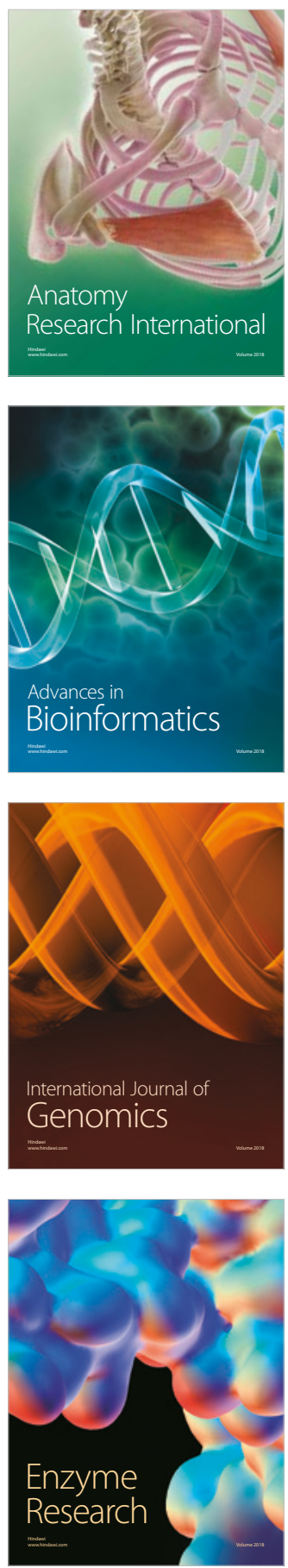
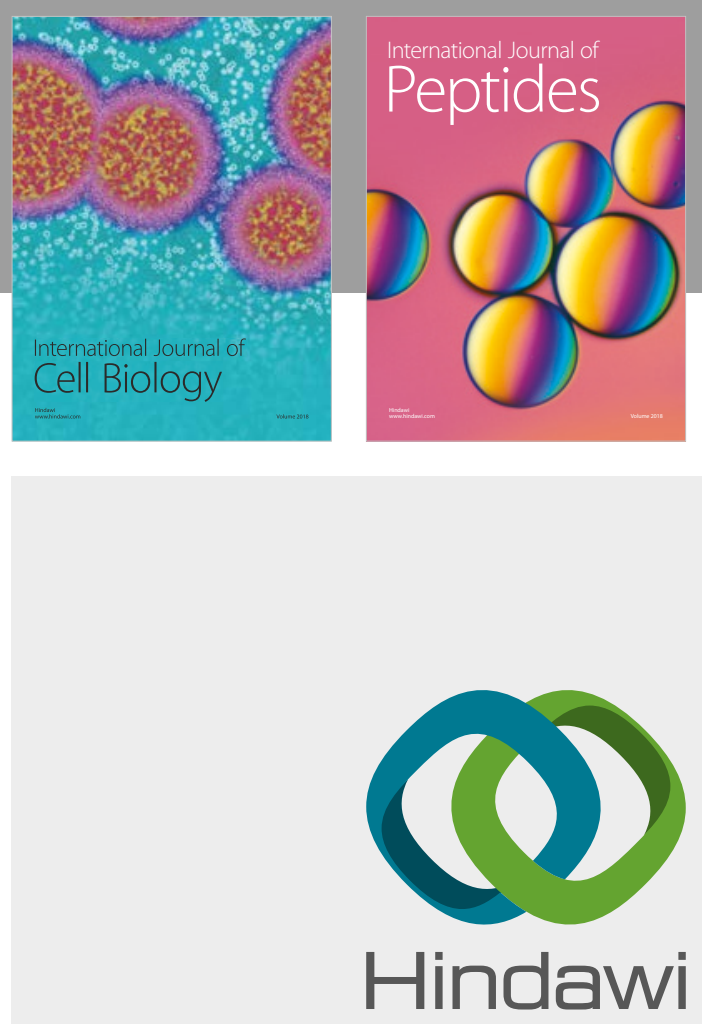

Submit your manuscripts at

www.hindawi.com
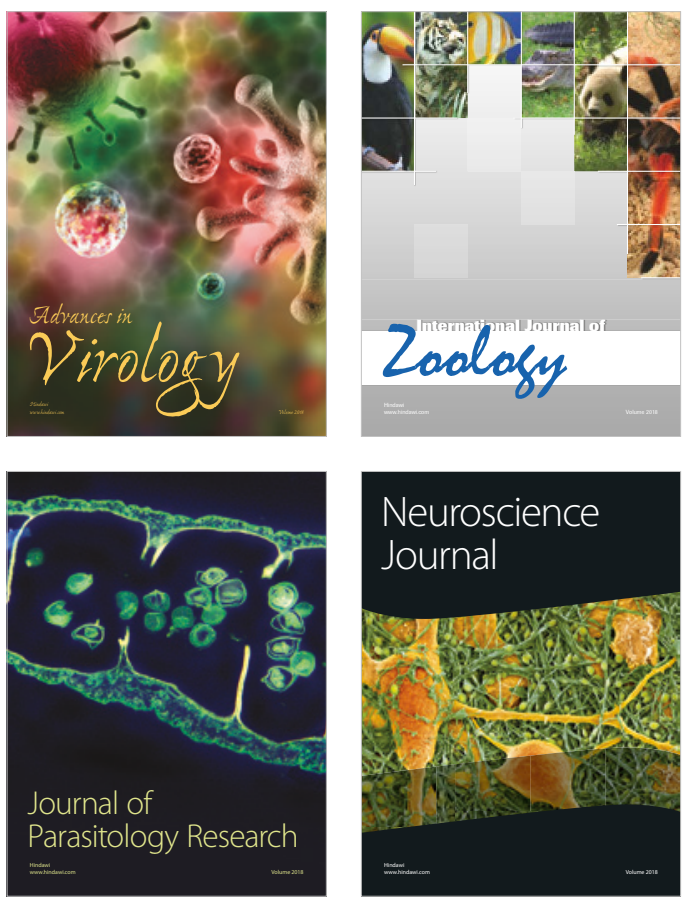
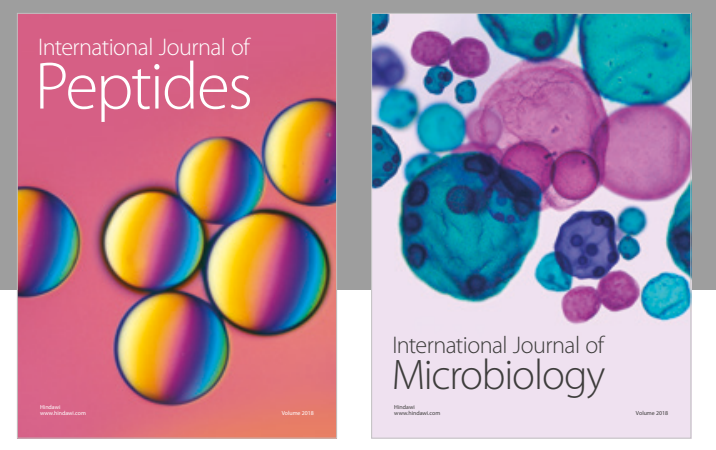

nternational Journal of Microbiology
Journal of
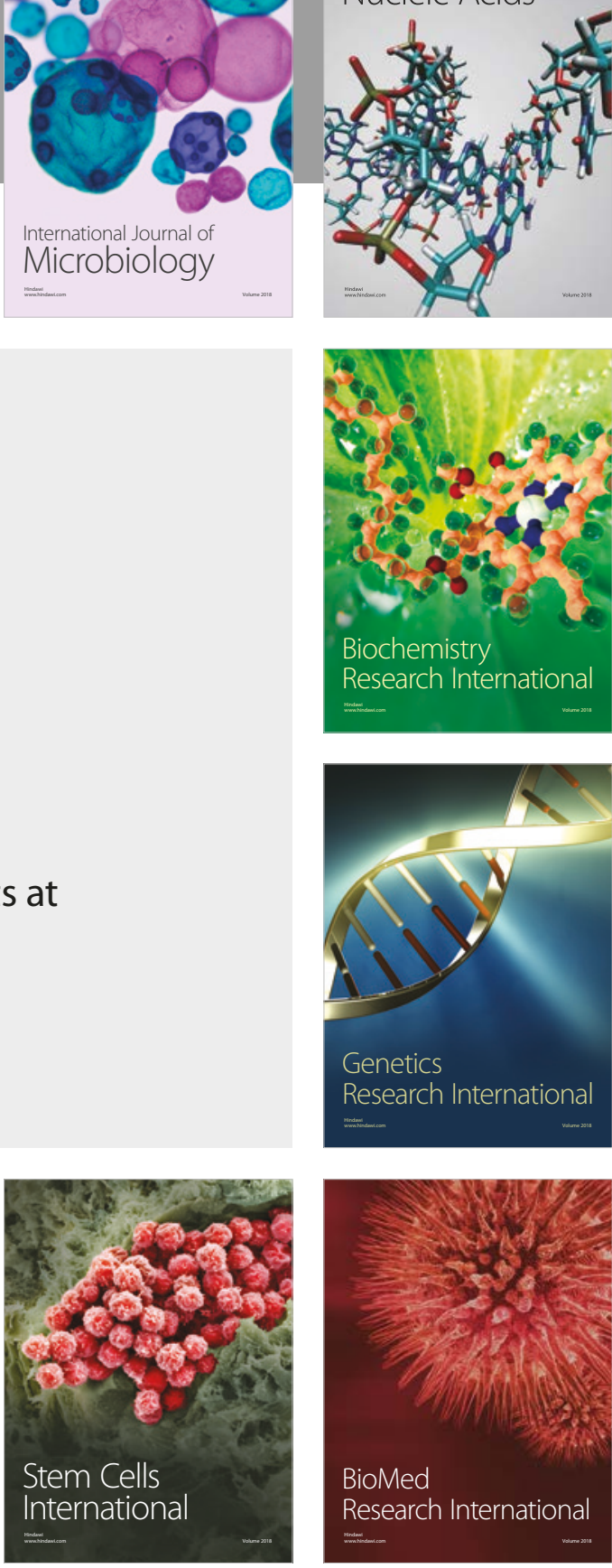
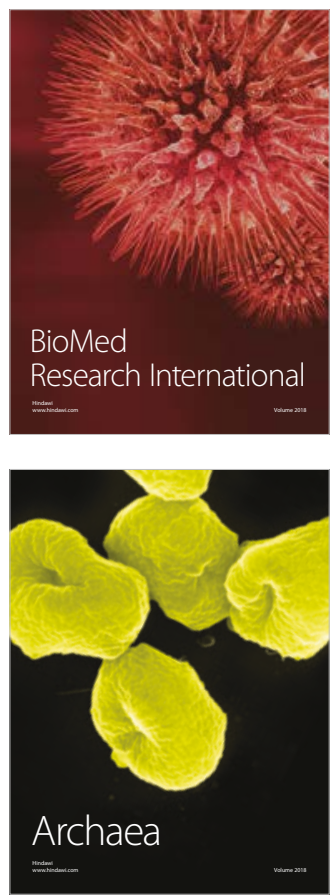